\title{
THE WORKING CAPITAL MANAGEMENT ON THE PROFITABILITY OF LISTED FIRMS: EVIDENCE FROM CREDIT RATING AGENCY MONITORING ON FTSE 100 COMPANIES
}

\author{
Saygun KEREM ${ }^{1}$ \\ Boren SARGON ${ }^{2}$
}

\begin{abstract}
Underlying research tries to assess the impact of the credit rating monitoring on the working capital management and thus the impact on the overall profitability of the non-financial FTSE 100 firms. We used Return on Assets (ROA), Return on Equity (ROE), and Tobin $Q$ as the profitabiliy proxies. The first two measures represent the accounting firm's performance, while the latter is used as market profitability. The Cash Conversion Cycle (CCC) was used in this study to proxy working capital like many others in the preceding literature. Our findings suggest that aggressive working capital management is still the key to corporate profitability for non-financial FTSE100 firms when ROE is used. However, it supports the conservative working capital policy when Tobin $Q$ is employed as a profitability measure. Nevertheless, when credit rating agency monitoring is in place, we can disclose a different story. Findings from this study using the System GMM methodology outline that when credit rating agencies' credit rating monitoring is in place, firms tend to spread the time for CCC. Relative to the previous statement, the firms that are not monitored are likely to shorten the CCC for attaining a higher profit level for the accounting measures of ROA and ROE. Nevertheless, we could not be able to find similar results with the Random effect (RE) models. We believe that the endogenous nature of the variables used in this study could trigger the insignificant impact of credit rating monitoring while using the RE models.
\end{abstract}

Keywords: Cash Conversion Cycle, Working Capital Management, Credit Rating Monitoring

JEL Codes: C23, G24, M20, O30

\section{ISSLETME SERMAYESI YÖNETIMININN BORSADA İŞLEM GÖREN FIRMALARIN KURUMSAL KÂRLILIĞINA İLISSKIIN ETKISSI: FTSE 100 ŞİRKETLERINIIN KREDİ DERECELENDIRME NOTLARINA İLIŞKIIN KANITLAR}

\begin{abstract}
$\ddot{\mathbf{O} z}$
Bu aratırma kredi notu izlemesinin işletme sermayesi yönetimi üzerindeki etkisini ve dolayısıla finansal olmayan FTSE 100 firmalarının genel karlılı̆̆ üzerindeki etkisini değerlendirmeye çalışmaktadır. Kârlılık ölçümü olarak bu çalışmada Varlık Getirisi (ROA), Özsermaye Getirisi (ROE) ve Tobin Q'yu kullanılmıştır. Illk iki ölçü muhasebe firmasının performansını temsil ederken, ikincisi piyasa karlılı̆̆ı olarak kullanılmıştır. Nakit Dönüş̧ürme Döngüsü (CCC), önceki literatürdeki diğerleri gibi işletme sermayesini temsil etmek için bu çalışmada kullanılmıştır. Bulgularımız, ROE kullanıldı̆̆ında finansal olmayan FTSE100 firmaları için agresif işletme sermayesi yönetiminin hala kurumsal karlılı̆̆ın anahtarı olduğunu göstermektedir. Ancak, Tobin Q bir kârlılık ölçüsü olarak kullanıldı̆̆ında muhafazakar işletme sermayesi politikasını desteklemektedir. Bununla birlikte, kredi derecelendirme kuruluşu denetimi yapıldığında, farklı bir hikaye açıklayabiliriz. System GMM metodolojisini kullanan bu çalışmadan elde edilen bulgular, kredi derecelendirme kuruluşlarının kredi derecelendirme izlemesi yapıldı̆̆ında, firmaların CCC için süreyi yayma ĕ̆iliminde olduğunu özetlemektedir. Bir önceki açılklamaya göre, izlenmeyen firmaların ROA ve ROE'nin muhasebe ölçütleri için daha yüksek bir kar seviyesine ulaşmak için CCC'yi kısaltması muhtemeldir. Yine de Rastgele etki (RE) modelleri ile benzer sonuçlara ulaşamadık. Bu çalışmada kullanılan değişkenlerin içsel doğasının, RE modellerini kullanırken kredi notu izlemenin önemsiz etkisini tetikleyebileceğini düşünüyoruz.
\end{abstract}

Anahtar Kelimeler: Nakit Dönüştürme Döngüsü, İşletme Sermayesi Yönetimi, Kredilendirme Şirketi İzlemesi JEL Kodları: C23, G24, M20, O30

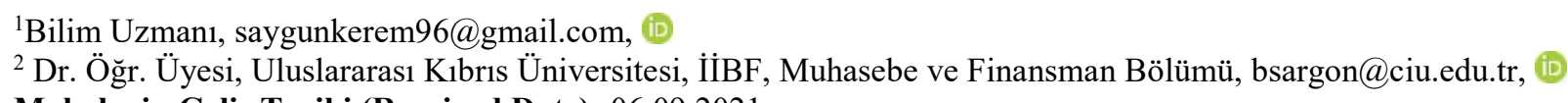

Makalenin Geliş Tarihi (Received Date): 06.09.2021

Revizyon Tarihi (Revised Date): 26.09.2021

Yayına Kabul Tarihi (Acceptance Date): 30.12.2021

Atıf (Citation): Sargon, B. \& Kerem, S. (2021), "The Working Capital Management on the Profitability of Listed Firms: Evidence from Credit Rating Agency Monitoring on FTSE 100 Companies”, Ekonomi Maliye İşletme Dergisi, 4(2): 145 154 


\section{Introduction}

There have been more studies about the relationship between long-term investment decisions and financial performance or stock prices related to Capital Asset Pricing Model in the past literature. Still, we must realize that working capital management (WCM) plays a vital role in the firm's competitive advantage. A financial manager devotes most of their time to WCM on a day-to-day basis (Besley and Brigham, 2008). Last two decades, some significant studies linked firm performance to effective WCM procedures. Moreover, lean WCM has been linked with the failure of most small and medium-sized enterprises (SMEs), according to Cielen, Peeters, \& Vanhoof (2004). Exemplar, one of the first studies which pointed out the importance of using WCM effectively is given by Shin and Soenen (1998). Evidence from their research suggests that futile WCM played a significant role in Kmart's bankruptcy even when the capital structure of Kmart was similar to Wal-Mart's during that time. Although working capital is a short-term management procedure, Chang (2018) argues that sometimes it can become a genuine way of gaining profit.

Considering the trade-off theory (Myers, 1984), leverage aids in raising the firm value. By increasing leverage, corporations eventually decrease their excessive cash holdings and exploit the tax benefits of debt. It is argued that excessive cash holding does not always support new projects or growth. Instead, it is usually used for covering losses, so it only "burns a hole in management's pockets" (Opler, Pinkowitz, Stulz, \& Williamson, 1999). The recent findings show that the firms who have a higher tendency for holding cash are the firms with more financial constraints, so that they hold cash because of their need for more top hedging (Acharya, Almeida, \& Campello, 2007; Almeida, Campello, \& Weisbach, 2004).

On the contrary, large firms have easier access to capital markets. Those with high credit ratings tend to hold lower cash amounts concerning their non-cash assets (Opler, et al., 1999). There are several reasons behind this; firstly, holding excessive cash has an opportunity cost of not earning interest rates over time. Secondly, the trade-off theory implications assume leverage can help reduce cash holdings to some extent. These leverages preferably be the short-term trade credits from suppliers to obtain an optimal cash conversion cycle (CCC). Wang (2019) argues that operating leverage and cash holdings have an associated adverse relationship with the WCM proxy of CCC.

After some significant studies are done, the interest in researching the effects of WCM and liquidity on the firm's performance and profitability increases gradually every other day (Lyroudi and Lazaridis, 2000). To be more active in managing working capital, a manager should speed up collecting account receivables. They are slowing down the cash outflows, such as the trade credit payments to sellers, as much as possible to achieve a short but optimal CCC to have a better firm performance.

Put simply, WCM is defined as the effective management of current assets and current liabilities, according to many scholars in the field. An effective WCM minimizes the risk of inability to pay short-term commitments; therefore, it reduces the chance of default and loss of firm reputation.

The standard measurement for the WCM has been the CCC. It can be expressed as the days between the disbursement to suppliers and the collection of cash receipts from product sales. This period is further calculated by the total inventory days plus the accounts receivable conversion days minus the accounts payable conversion days. To improve profitability using the $\mathrm{CCC}$, a manager should lower accounts receivable and inventory accounts and extend the accounts payable days. By doing so, the company will have a shorter CCC, and a working capital policy that has an aggressive CCC can improve profitability (Yazdanfar and Öhman, 2014). Instead of using CCC, which gives days in their regression, some scholars preferred to use the net trade cycle.

Many scholars find a strong and negative relationship between WCM and the firm's profitability. Some of them used NTC to test the links (Baños-Caballero, García-Teruel, \& Martínez-Solano, 2012, 2014; Shin and Soenen, 1998) and others used CCC (Deloof, 2003; Karaduman, Akbas, Ozsozgun, \& Durer, 2010; Uyar, 2009). Moreover, while Karaduman, et al. (2010) used ROA and ROE to measure profitability, Deloof (2003) took gross operating income as a profitability measure. On the other hand, there are contradictory findings too, where a shorter CCC with aggressive WCM can reduce profits (Afza and Nazir, 2008; Baños-Caballero, et al., 2014; Dalci and Ozyapici, 2018). 
Kling, Paul, \& Gonis (2014) argued that when firms have excessive cash holdings, the supply-side effect suggests that suppliers might be willing to give more trade credit. Still, the availability of additional cash or trade credit will increase the days of CCC. Then again, Baños-Caballero, et al. (2014) discovered a U-shaped relationship between NTC length and corporate performance. They suggested an optimal level of working capital policy that balances the costs and benefits while maximizing the profitability of a company.

Davydenko (2013) studied the impact of liquidity on the firm's distress and showed a connection between the firm's chance of defaulting and liquidity. According to his study, cash-rich firms should be safer than firms with fewer cash holdings. In the study of cash holdings concerning the firm's credit rating, Joe and Oh (2018) found a shred of evidence in the Korean firms where credit rating sensitivities affect the cash holding policies. Khieu and Pyles (2012) concluded that downgraded firms increase their excessive cash holdings concerning firms that do not show a change in their credit ratings. Thus, the impact of liquidity management might be related to the issuer credit rating of the firm.

This paper will examine the relationship between WCM and profitability by using the interaction effect of credit monitoring with WCM. To our knowledge, there is no such research that outlines this relationship with the WCM and credit rating monitoring. The following section presents the story behind the sample, methodology, and variables used in the empirical analysis. Subsequently, there will be a discussion of our findings. The last section will give a brief conclusion about the whole study, and some implications will be provided.

\section{Data and Methodology}

The data used in this study were retrieved from the ORBIS database to cover 2011 through 2019. The sample consists of companies enlisted on the FTSE 100 index. We have excluded companies that do not use corporate accounting templates. In addition to this selection procedure, we have excluded companies with missing data. Finally, we ended with a final sample of 45 non-financial FTSE100 companies. We also winsorized the data at 5 percent level to remove the potential existence of outliers.

Our analysis is mainly based on the System GMM methodology proposed by Arellano and Bover (1995) and Blundell and Bond (1998). The motive to choose systematic GMM over other methods is primarily influenced by the endogenous nature of the variables such as WCM and profitability.

We have employed the following equations for the system GMM specifications:

$$
\begin{aligned}
\Pi_{\mathrm{i}, \mathrm{t}}= & \beta_{0}+\beta_{1} \Pi_{i, t-1}+\beta_{2} C C C_{i, t}+\beta_{3} T A N G_{i, t}+\beta_{4} L E V_{i, t}+\beta_{5} C A_{i, t}+\beta_{6} S G_{i, t}+ \\
& \beta_{7} S I Z E+\lambda_{t}+\eta_{i}+\varepsilon_{i, t} \\
\Pi_{\mathrm{i}, \mathrm{t}}= & \beta_{0}+\beta_{1} \Pi_{i, t-1}+\beta_{2} C C C_{i, t}+\beta_{3} T A N G_{i, t}+\beta_{4} L E V_{i, t}+\beta_{5} C A_{i, t}+\beta_{6} S G_{i, t}+ \\
& \beta_{7} S I Z E+\beta_{8} C R E D I T_{i, t}+\beta_{9} C C C \times \text { Credit }_{i, t}+\lambda_{t}+\eta_{i}+\varepsilon_{i, t}
\end{aligned}
$$

Also, we report the following RE models to compare the results with the GMM methodology employed in this study. The next model tries to capture the same impact, mainly based on Equations 1 and 2.

$$
\begin{aligned}
\Pi_{\mathrm{i}, \mathrm{t}}= & \beta_{0}+\beta_{1} C C C_{i, t}+\beta_{2} T A N G_{i, t}+\beta_{3} L E V_{i, t}+\beta_{4} C A_{i, t}+\beta_{5} S G_{i, t}+\beta_{6} S I Z E+a_{i}+ \\
& \varepsilon_{i t} \\
\Pi_{\mathrm{i}, \mathrm{t}}= & \beta_{0}+\beta_{1} C C C_{i, t}+\beta_{2} T A N G_{i, t}+\beta_{3} L E V_{i, t}+\beta_{4} C A_{i, t}+\beta_{5} S G_{i, t}+\beta_{6} S I Z E+ \\
& \beta_{7} C R E D I T_{i, t}+\beta_{8}(C C C \times C R E D I T)_{i, t}+a_{i}+\varepsilon_{i t}
\end{aligned}
$$

Where $a_{i t}$ is the unobserved effect for random effect models and $\varepsilon_{i t}$ is the error term. GMM models represented with Equation 1 and 2 are also estimated with the equations above (Equation 3 and 4), respectively. 
We have employed several proxies to measure the profitability of the company. We have both employed the corporate market measure of Tobin's $\mathrm{Q}$ and the accounting profitability measures of return on asset (ROA) and return on equity (ROE).

We have employed the CCC as the proxy of the WCM. Additionally, we formed a dummy variable to measure if the credit rating company monitors the company. This dummy variable takes the value of 1 if a credit rating agency rates a company. We used the dummy variable of CREDIT to measure the interaction effect of Credit rating monitoring on the CCC $(C C C \times C R E D I T)$. The remaining variables demonstrated the control variables: Tangibility which measures the ratio of tangible assets to total assets (Dalci and Ozyapici, 2018). Sales Growth (SG) is the difference between current and previous value and is divided into the prior value of the sales (Dalci and Ozyapici, 2018; Deloof, 2003). Leverage is the ratio of total debt to total assets (Baños-Caballero, García-Teruel, \& MartínezSolano, 2010; Chang, 2018; Dalci and Ozyapici, 2018). Current Ratio (CA) is the static measure of WCM represented by the ratio of current assets to current liabilities(Dalci and Ozyapici, 2018). Lastly, the company's size (SIZE) is the logarithmic form of net sales to normalize the data (Dalci and Ozyapici, 2018; Yazdanfar and Öhman, 2014).

To check the validity of our models, we have tested expanded regressions to check endogeneity issues using the Hansen J test. We also checked the exogeneity of instruments via the Stock and Yogo (2002) procedure by the existence of weak instruments of the data. The endogenous nature of some variables leads us to select a model that surpasses the problem of endogeneity.

We have selected system GMM instead of difference GMM due to the procedure recommended by (Bond, Hoeffler, \& Temple, 2001). They suggested estimating the equation with the Pooled OLS methodology, and the LSDV approach will advise which model can be chosen. Our Pooled OLS and LSDV regressions not reported here clearly showed that System GMM is much more efficient than difference GMM methodology. Additionally, we have employed bootstrapped robust Hausman test to select between RE and FE models, recommended by Sargon and Katircioğlu (2019). Our results from the Bootstrapped Hausman Test outlines that RE models are superior to FE models; thus, we do not report them in this study.

\section{Empirical Results}

Table 1 shows the descriptive statistics and the correlation coefficients for the variables used in this study. We have reported the pairwise correlations along with their significance.

Table1: Pairwise correlations

\begin{tabular}{|c|c|c|c|c|c|c|c|c|c|c|c|}
\hline Variables & -1 & -2 & -3 & -4 & -5 & -6 & -7 & -8 & -9 & -10 & -11 \\
\hline (1) TOBINQ & 1 & & & & & & & & & & \\
\hline (2) ROA & $0.222 *$ & 1 & & & & & & & & & \\
\hline (3) $\mathrm{ROE}$ & $0.182 *$ & $0.752 *$ & 1 & & & & & & & & \\
\hline (4) $\mathrm{CCC}$ & $0.288^{*}$ & $0.135^{*}$ & $0.102 *$ & 1 & & & & & & & \\
\hline (5) TANGIBILITY & $-0.143 *$ & -0.061 & -0.092 & $-0.184 *$ & 1 & & & & & & \\
\hline (6) LEVERAGE & 0.019 & -0.084 & 0.076 & $-0.103 *$ & $0.112 *$ & 1 & & & & & \\
\hline (7) $\mathrm{CA}$ & $0.140^{*}$ & $0.170^{*}$ & -0.025 & $0.474 *$ & -0.044 & $-0.409 *$ & 1 & & & & \\
\hline (8) $\mathrm{SG}$ & 0.078 & 0.071 & 0.008 & $0.103^{*}$ & -0.004 & $-0.150^{*}$ & 0.091 & 1 & & & \\
\hline (9) SIZE & $-0.556^{*}$ & $-0.210 *$ & 0.025 & $-0.361 *$ & 0.069 & $0.205^{*}$ & $-0.493 *$ & $-0.146^{*}$ & 1 & & \\
\hline (10) CREDIT & $-0.173^{*}$ & -0.057 & 0.089 & -0.054 & 0.079 & $0.134 *$ & $-0.170^{*}$ & -0.087 & $0.483 *$ & 1 & \\
\hline (11) CCC*CREDIT & $0.146^{*}$ & 0.046 & 0.083 & $0.544 *$ & -0.059 & $0.130 *$ & $0.226^{*}$ & -0.037 & -0.073 & $0.464 *$ & 1 \\
\hline
\end{tabular}

Table 2 reports the findings for the system GMM and RE specification for Equation 1 and Equation 2 reported above. The first model constructs System GMM regression tries to mimic the previous literature. The model does not address any flaws. The diagnostics such as AR(2) coefficient are not significant, and Hansen statistics show that our model is stable. The lagged value of the Tobin $Q$ shows a high persistence level of market profits. We found that the WCM proxy of CCC is significant at a level of 10 percent. Working capital management exerts a positive impact on profitability. 
Contrary to the literature, our results show a different story. Our findings of the conservative policy of working capital management exert profitability can be justified by the findings of Chang (2018). He outlines that low CCC level firms become more profitable in contrast to high CCC firms. For these firms, a conservative working capital management policy might be more common NonFinancial FTSE100 firms. These firms are likely to keep a low level of CCC.

Additionally, we could find some significant results with CA and SG, which is in line with the literature. This suggests that keeping a high level of current assets mitigates market profitability. In contrast, increases in sales year-to-year basis will increase profitability.

The second model attempts to mimic the first model with the assumption of no potential endogeneity problem. Our findings are like the System GMM model with few alterations. Our finding of conservative working capital policy yields more profitability also justified with this model along with a higher level of significance. Additionally, we could observe that TANGIBILITY and LEVERAGE exert a significant negative impact on profitability. Moreover, the effect of SG is still positive. However, the significance level is somewhat lessened in contrast with Model 1.

Table 2: Regression Outputs for Model 1-4

\begin{tabular}{|c|c|c|c|c|}
\hline & System GMM & $\mathrm{RE}$ & System GMM & $\mathrm{RE}$ \\
\hline & Tobin Q & Tobin Q & Tobin Q & Tobin Q \\
\hline \multirow[t]{2}{*}{ L.Tobin Q } & $0.7343^{* * * *}$ & & $0.6819^{* * * *}$ & \\
\hline & $(5.6961)$ & & $(11.5357)$ & \\
\hline \multirow[t]{2}{*}{$\mathrm{CCC}$} & $0.0018^{* *}$ & $0.0025^{* * * *}$ & $-0.0032^{* * * *}$ & $0.0020^{* * * *}$ \\
\hline & $(2.4929)$ & $(3.7155)$ & $(-4.3918)$ & $(3.9379)$ \\
\hline \multirow[t]{2}{*}{ TANGIBILITY } & -0.0493 & $-0.8688^{* *}$ & $-0.4741^{* *}$ & $-0.8819^{* * *}$ \\
\hline & $(-0.2916)$ & $(-2.5561)$ & $(-2.6725)$ & $(-2.6070)$ \\
\hline \multirow[t]{2}{*}{ LEVERAGE } & -0.0018 & $-0.0092^{* *}$ & -0.0015 & $-0.0097^{* *}$ \\
\hline & $(-0.1829)$ & $(-1.9887)$ & $(-0.3530)$ & $(-2.1008)$ \\
\hline \multirow[t]{2}{*}{$\mathrm{CA}$} & $-0.1682^{* *}$ & -0.0427 & 0.0112 & -0.0489 \\
\hline & $(-2.0776)$ & $(-0.5328)$ & $(0.1597)$ & $(-0.6066)$ \\
\hline \multirow[t]{2}{*}{ SG } & $0.0152^{* * *}$ & $0.0057^{* *}$ & $0.0044^{* * * *}$ & $0.0059^{* *}$ \\
\hline & $(3.5221)$ & $(2.3957)$ & $(3.8939)$ & $(2.5583)$ \\
\hline \multirow[t]{2}{*}{ SIZE } & -0.0805 & -0.1011 & $-0.1964^{* * * *}$ & -0.0893 \\
\hline & $(-1.3087)$ & $(-1.3498)$ & $(-6.4149)$ & $(-1.0421)$ \\
\hline \multirow[t]{2}{*}{ CREDIT } & & & -0.0851 & -0.1547 \\
\hline & & & $(-0.9540)$ & $(-0.6670)$ \\
\hline \multirow[t]{2}{*}{ CCC_CREDIT } & & & $0.0036^{* * *}$ & 0.0018 \\
\hline & & & $(2.7864)$ & (1.3119) \\
\hline \multirow[t]{2}{*}{ Constant } & 2.1882 & $3.7795^{* *}$ & $5.2550^{* * * * *}$ & $3.6024^{*}$ \\
\hline & $(1.1611)$ & $(2.0236)$ & $(6.6139)$ & $(1.7405)$ \\
\hline Observations & 360 & 405 & 360 & 405 \\
\hline Hansen Stat. & 29.3107 & & 21.9888 & \\
\hline F stat. & $238.8182 * * * *$ & & $351.6450 * * * *$ & \\
\hline AR1 & $-3.4892 * * * *$ & & $-3.3762 * * * *$ & \\
\hline AR2 & 0.1524 & & -0.0484 & \\
\hline Wald Chi2 & & $103.7974 * * * *$ & & $110.5594 * * * *$ \\
\hline R2 Overall & & 0.1773 & & 0.1797 \\
\hline
\end{tabular}

The third model tries to test the moderating impact of credit rating on the working capital management proxy, CCC. We could estimate our model without any problem of autocorrelation, model fit, and validity of the instruments used in the model. This model shows that the persistence of the market profitability is somewhat mitigated compared to the previous counterpart but still significant. The introduction of credit rating dummy and moderating impact for the model justified a reversal impact on the working capital management which made our findings in line with the literature; thus, aggressive working capital management boosting impact is justified. The most crucial finding in this model is relatively the findings extracted from the moderating variable. Although we could not find significant results with the credit dummy, we could be able to find some boosting effect of the credit ratings on $\mathrm{CCC}$. This finding suggests that companies under constant monitoring by the credit rating 
agencies might choose conservative liquidity management to upturn the profitability levels. In addition to this, we could negatively significant results for TANGIBILITY and SIZE and positive for the SIZE variable, which follows a similar path with the existing literature.

Model 4 is the mimicked version of Model 3. This model follows similar findings with Model 2. However, we could not find a shred of evidence that credit rating affects profitability. We believe that the endogeneity of other variables led to these results.

Table 3: Regression Outputs for Model 5-8

\begin{tabular}{|c|c|c|c|c|}
\hline & $\begin{array}{c}\text { System GMM } \\
\text { ROA } \\
\end{array}$ & $\begin{array}{c}\mathrm{RE} \\
\mathrm{ROA} \\
\end{array}$ & $\begin{array}{c}\text { System GMM } \\
\text { ROA } \\
\end{array}$ & $\begin{array}{c}\mathrm{RE} \\
\mathrm{ROA} \\
\end{array}$ \\
\hline L.ROA & $\begin{array}{l}0.6138^{* * * *} \\
(12.6333)\end{array}$ & & $\begin{array}{l}0.4532^{* * * *} \\
(10.2040)\end{array}$ & \\
\hline $\mathrm{CCC}$ & $\begin{array}{c}0.0038 \\
(1.4945)\end{array}$ & $\begin{array}{c}0.0060 \\
(1.2114)\end{array}$ & $\begin{array}{c}0.0117 \\
(1.6297)\end{array}$ & $\begin{array}{c}0.0057 \\
(0.8075)\end{array}$ \\
\hline TANGIBILITY & $\begin{array}{l}9.6135^{*} \\
(1.8702)\end{array}$ & $\begin{array}{l}-1.6171 \\
(-0.8039)\end{array}$ & $\begin{array}{l}13.1197^{*} \\
(2.0065)\end{array}$ & $\begin{array}{l}-1.6257 \\
(-0.8090)\end{array}$ \\
\hline LEVERAGE & $\begin{array}{l}-0.0620 \\
(-1.3670)\end{array}$ & $\begin{array}{l}-0.0526 \\
(-1.4575)\end{array}$ & $\begin{array}{l}-0.0194 \\
(-1.1184)\end{array}$ & $\begin{array}{l}-0.0536 \\
(-1.4182)\end{array}$ \\
\hline $\mathrm{CA}$ & $\begin{array}{l}-1.2549 \\
(-1.5146)\end{array}$ & $\begin{array}{c}0.5236 \\
(0.7676)\end{array}$ & $\begin{array}{l}-0.1613 \\
(-0.3881)\end{array}$ & $\begin{array}{c}0.5299 \\
(0.7780)\end{array}$ \\
\hline SG & $\begin{array}{c}0.0142 \\
(1.2482)\end{array}$ & $\begin{array}{c}-0.0042 \\
(-0.1829)\end{array}$ & $\begin{array}{c}0.0104 \\
(0.8534)\end{array}$ & $\begin{array}{l}-0.0041 \\
(-0.1776)\end{array}$ \\
\hline SALES & $\begin{array}{l}-1.0579 \\
(-1.0557)\end{array}$ & $\begin{array}{c}0.0441 \\
(0.0763)\end{array}$ & $\begin{array}{l}-1.0452^{* * *} \\
(-2.7923)\end{array}$ & $\begin{array}{c}0.1067 \\
(0.1630)\end{array}$ \\
\hline CREDIT & & & $\begin{array}{l}2.0914^{* *} \\
(2.2181)\end{array}$ & $\begin{array}{l}-0.3028 \\
(-0.2103)\end{array}$ \\
\hline CCC_CREDIT & & & $\begin{array}{l}-0.0252^{*} \\
(-1.7052)\end{array}$ & $\begin{array}{c}0.0014 \\
(0.1003)\end{array}$ \\
\hline Constant & $\begin{array}{l}29.6885 \\
(1.3285)\end{array}$ & $\begin{array}{c}7.6663 \\
(0.5471)\end{array}$ & $\begin{array}{c}25.0186^{* * *} \\
(2.8226)\end{array}$ & $\begin{array}{c}6.3975 \\
(0.4161)\end{array}$ \\
\hline Observations & 360 & 405 & 360 & 405 \\
\hline Hansen Stat. & 33.6855 & & 27.5486 & \\
\hline F stat. & 750.7847 & & 425.7270 & \\
\hline AR1 & $-3.2664 * * * *$ & & $-3.4353 * * * *$ & \\
\hline AR2 & -0.2093 & & -0.3136 & \\
\hline Wald Chi2 & & $31.5078 * * * *$ & & $32.8011 * * * *$ \\
\hline R2 Overall & & 0.0425 & & 0.0403 \\
\hline
\end{tabular}

In models 5-7, we did try to check the impact of our hypotheses on the accounting profitability of ROA. Previous results with Tobin $\mathrm{Q}$ found a shred of evidence that credit rating agencies' monitoring matters. We expect that we are less likely to find a significant impact because these companies are being listed in the market. While Model 5 and Model 6 try to check the existing relationship between working capital management and profitability using System GMM and RE, the remaining tries to introduce credit dummy and the interaction effect of credit rating on the CCC.

Surprisingly, we could not able construct numerous significant connections as we suspected. The coefficient for lagged ROA is relatively high. It suggests that the persistence of profitability is continuous, just like the models with the TOBIN Q as the dependent variable. The liquidity management variable of CCC does not exert any impact on corporate profitability. Although the aggressive policy is previously documented to have a profitability-boosting effect, using a linear relationship between working capital management and profitability could not be justified by previous scholars (Baños-Caballero, et al., 2012; Deloof, 2003). In addition to the persistence of the ROA profitability, we can only find a trace of evidence that increased tangible assets will lead to more profitability.

Model 6, which is the RE estimation again, could not give any significant findings that accounting performance is affected by these variables. The findings extracted from this model outline that accounting profitability is likely to be affected. Additionally, there is a possibility that working capital management is likely to have a non-linear relationship that we did not test over at this model. Also, the endogenous nature of the variables might have affected as well (Baños-Caballero, et al., 2014). 
Model 7 investigates the working capital model, proving that adding credit rating monitoring multiplied the significance level for some of the variables used in this model. Previously we observed that the CCC variable is solely not significant. However, we could able to identify that credit monitoring intensifies profitability. However, on the contrary, the moderating variable supports the aggressive working capital policy. Consecutively the last model, which considers the ROA as the dependent variable with RE estimation, suggests that no significant results can be found.

Table 4: Regression Outputs for Model 9-12

\begin{tabular}{|c|c|c|c|c|}
\hline & ROE & ROE & ROE & ROE \\
\hline \multicolumn{5}{|l|}{ L.Tobin Q } \\
\hline \multicolumn{5}{|l|}{ L.ROA } \\
\hline L.ROE & $\begin{array}{l}0.4680^{* * * *} \\
(13.9364)\end{array}$ & & $\begin{array}{l}0.4579^{* * * *} \\
(10.4470)\end{array}$ & \\
\hline $\mathrm{CCC}$ & $\begin{array}{l}-0.0477^{* *} \\
(-2.5914)\end{array}$ & $\begin{array}{c}0.0175 \\
(1.2770)\end{array}$ & $\begin{array}{c}-0.0309^{*} \\
(-1.9954)\end{array}$ & $\begin{array}{c}0.0214 \\
(1.2506)\end{array}$ \\
\hline TANGIBILITY & $\begin{array}{c}34.2945^{* *} \\
(2.0380)\end{array}$ & $\begin{array}{c}-3.1322 \\
(-0.3837)\end{array}$ & $\begin{array}{c}3.0641 \\
(0.2921)\end{array}$ & $\begin{array}{c}-3.2583 \\
(-0.4041)\end{array}$ \\
\hline LEVERAGE & $\begin{array}{c}0.3397^{* * * *} \\
(7.1760)\end{array}$ & $\begin{array}{c}-0.0142 \\
(-0.1392)\end{array}$ & $\begin{array}{c}0.4501^{* * * *} \\
(7.9408)\end{array}$ & $\begin{array}{c}-0.0116 \\
(-0.1132)\end{array}$ \\
\hline $\mathrm{CA}$ & $\begin{array}{l}4.8126^{* *} \\
(2.0562)\end{array}$ & $\begin{array}{l}1.5107 \\
(0.8250)\end{array}$ & $\begin{array}{c}9.9150^{* * * *} \\
(4.9830)\end{array}$ & $\begin{array}{c}1.5674 \\
(0.8626)\end{array}$ \\
\hline SG & $\begin{array}{c}0.0525 \\
(1.2396)\end{array}$ & $\begin{array}{c}-0.0236 \\
(-0.3373)\end{array}$ & $\begin{array}{c}0.0512 \\
(1.3576)\end{array}$ & $\begin{array}{c}-0.0243 \\
(-0.3447)\end{array}$ \\
\hline SALES & $\begin{array}{l}-7.9185^{* *} \\
(-2.5170)\end{array}$ & $\begin{array}{c}1.3860 \\
(1.0355)\end{array}$ & $\begin{array}{l}-9.5275^{* *} \\
(-2.5050)\end{array}$ & $\begin{array}{c}0.9705 \\
(0.6021)\end{array}$ \\
\hline CREDIT & & & $\begin{array}{c}18.0040^{* * * * *} \\
(3.6360)\end{array}$ & $\begin{array}{c}2.9517 \\
(0.7636)\end{array}$ \\
\hline CCC_CREDIT & & & $\begin{array}{l}-0.0857^{* *} \\
(-2.1053)\end{array}$ & $\begin{array}{c}-0.0161 \\
(-0.3916)\end{array}$ \\
\hline Constant & $\begin{array}{c}171.5056^{* *} \\
(2.3483)\end{array}$ & $\begin{array}{l}-12.5390 \\
(-0.3964)\end{array}$ & $\begin{array}{c}195.5052^{* *} \\
(2.2347)\end{array}$ & $\begin{array}{c}-4.5527 \\
(-0.1246)\end{array}$ \\
\hline Observations & 360 & 405 & 360 & 405 \\
\hline Hansen Stat. & 24.5483 & & 28.2410 & \\
\hline F stat. & 5810.2317 & & 2130.6915 & \\
\hline AR1 & $-3.2907 * * *$ & & $-3.3020 * * *$ & \\
\hline AR2 & -1.8307 & & -1.7615 & \\
\hline Wald Chi2 & & $31.6269^{* * * *}$ & & 31.6881 **** \\
\hline R2 Overall & & 0.0339 & & 0.0389 \\
\hline
\end{tabular}

Lastly, we tried to look at our last accounting measure of profitability at Model 9-12. If we summarize our findings from this model, we could able to similar persistence of profits with highly significant levels. Additionally, we can only find a significant relationship between working capital profitability at System GMM Models. We documented that aggregate working capital policy is in place following the literature. The other findings include the following: the credit rating and companies monitored by the credit rating agencies are following conservative aggressive policy, leading to more profitability.

\section{Conclusion}

This study tried to capture the impact of credit agency monitoring on CCC on the firms traded in the FTSE 100 index. Thus, how does this impact counter-effect the corporate profitability of the nonfinancial firms in the FTSE 100 index? We tried to search this evidence through Non-Financial UKlisted firms. The panel setting of the work tried to give us individual effects on the firms' profitability. We tried to employ both the System GMM, where the model has some correctability against the endogenous nature. Along with the System GMM models, we tried to report RE models further to support our findings in this piece of work.

For this study, we tested the existing relationship in the literature and the hypothesized impact of credit rating on profitability via WCM management. To analyze the impact of credit monitoring, we 
have used accounting profitability and market profitability to justify our results. We could land with some mixed results according to which setting was used. Our comprehensive range of conservative, no impact, and aggressive policy results depends on which profitability measure is used. Mimicking the literature, we could find that conservative working capital policy creates a path for profitability relative to accounting measure $\mathrm{ROE}$, which promotes that aggressive working capital policy is valid for increasing corporate performance.

Our results also contribute to 1ohow being monitored via a credit agency affects the profitability via the firm's working capital management. Results documented in this study tip for a reversal effect when monitored by a credit rating agency. The documentation of our results leads to two different explanations in this case. The market profitability is likely to increase with conservative WCM policy if the company is monitored, and the reverse is true for those not monitored. In addition, being monitored leads firms to follow aggressive working capital policies. This difference between market and accounting profitability determines how firms value profitability.

For future research, it is possible to investigate how different quantiles of CCC might affect profitability using credit ratings.

Yazar Katkı Oranı (Author Contributions): Saygun KEREM (\%70), Boren SARGON (\%30)

Yazarların Etik Sorumlulukları (Ethical Responsibilities of Authors): Bu çalışma bilimsel araştırma ve yayın etiği kurallarına uygun olarak hazırlanmıştır.

Çıkar Çatışması (Conflicts of Interest) : Çalışmadan kaynaklı çıkar çatışması bulunmamaktadır.

İntihal Denetimi (Plagiarism Checking): Bu çalışma intihal tarama programı kullanılarak intihal taramasından geçirilmiştir. 


\section{REFERENCES}

Acharya, V. V., Almeida, H., \& Campello, M. (2007). "Is Cash Negative Debt? A Hedging Perspective on Corporate Financial Policies". Journal of Financial Intermediation, 16(4): 515-554.

Afza, T., \& Nazir, M. S. (2008). "Working Capital Approaches and Firm's Returns in Pakistan". Pakistan Journal of Commerce and Social Sciences (PJCSS), 1: 25-36.

Almeida, H., Campello, M., \& Weisbach, M. S. (2004). "The Cash Flow Sensitivity of Cash". The Journal of Finance, 59(4): 1777-1804.

Arellano, M., \& Bover, O. (1995). "Another Look at the Instrumental Variable Estimation of ErrorComponents Models". Journal of Econometrics, 68(1): 29-51.

Baños-Caballero, S., García-Teruel, P. J., \& Martínez-Solano, P. (2010). "Working Capital Management in SMEs". Accounting \& Finance, 50(3): 511-527.

Baños-Caballero, S., García-Teruel, P. J., \& Martínez-Solano, P. (2012). "How Does Working Capital Management Affect the Profitability of Spanish SMEs?". Small Business Economics, 39(2): 517-529.

Baños-Caballero, S., García-Teruel, P. J., \& Martínez-Solano, P. (2014). "Working Capital Management, Corporate Performance, and Financial Constraints". Journal of Business Research, 67(3): 332-338.

Besley, S., \& Brigham, E. F. (2008). Essentials of Managerial Finance: Thomson South-Western.

Blundell, R., \& Bond, S. (1998). "Initial Conditions and Moment Restrictions in Dynamic Panel Data Models”. Journal of Econometrics, 87(1): 115-143.

Bond, S. R., Hoeffler, A., \& Temple, J. R. (2001). GMM Estimation of Empirical Growth Models. No 2001-W21, Economics Papers, Economics Group, Nuffield College, University of Oxford.

Chang, C.-C. (2018). "Cash Conversion Cycle and Corporate Performance: Global Evidence". International Review of Economics \& Finance, 56: 568-581. doi:10.1016/j.iref.2017.12.014 Retrieved from $\quad<$ Go to $\quad$ ISI $>$ :/WOS:000435061200042, https://www.ncbi.nlm.nih.gov/pmc/articles/PMC6323624/pdf/main.pdf

Cielen, A., Peeters, L., \& Vanhoof, K. (2004). "Bankruptcy Prediction Using A Data Envelopment Analysis". European Journal of Operational Research, 154(2): 526-532. doi:10.1016/S03772217(03)00186-3 Retrieved from < Go to ISI $>$ ://WOS:000187779600014

Dalci, I., \& Ozyapici, H. (2018). "Working Capital Management Policy in Health Care: The Effect of Leverage". Health Policy, 122(11): 1266-1272. doi:10.1016/j.healthpol.2018.09.012 Retrieved from https://www.ncbi.nlm.nih.gov/pubmed/30274937

Davydenko, S. A. (2013). Insolvency, illiquidity, and the risk of default. Unpublished Work. University of Toronto. Toronto.

Deloof, M. (2003). "Does Working Capital Management Affect Profitability of Belgian Firms?". Journal of Business Finance \& Accounting, 30(3-4): 573-588. doi:10.1111/1468-5957.00008 Retrieved from https://onlinelibrary.wiley.com/doi/pdfdirect/10.1111/14685957.00008?download=true 
Joe, D. Y., \& Oh, F. D. (2018). "Credit Ratings and Corporate Cash Holdings: Evidence from Korea's Corporate Reform After the 1997 Asian Financial Crisis". Japan and the World Economy, 45: 9-18.

Karaduman, H. A., Akbas, H. E., Ozsozgun, A., \& Durer, S. (2010). "Effects of working capital management on profitability: the case for selected companies in the Istanbul stock exchange (2005-2008)". International Journal of Economics and Finance Studies, 2(2): 47-54.

Khieu, H. D., \& Pyles, M. K. (2012). “The Influence of a Credit Rating Change on Corporate Cash Holdings and Their Marginal Value”. Financial Review, 47(2): 351-373.

Kling, G., Paul, S. Y., \& Gonis, E. (2014). "Cash Holding, Trade Credit and Access to Short-Term Bank Finance”. International Review of Financial Analysis, 32: 123-131.

Lyroudi, K., \& Lazaridis, Y. (2000). "The Cash Conversion Cycle and Liquidity Analysis of the Food Industry in Greece". Available at SSRN: https://ssrn.com/abstract=236175 or http://dx.doi.org/10.2139/ssrn.236175

Myers, S. C. (1984). “The Capital Structure Puzzle”. Journal of Finance, 39(3): 575-592. Retrieved from $<$ Go to ISI $>$ ://WOS:A1984TB28800001

Opler, T., Pinkowitz, L., Stulz, R., \& Williamson, R. (1999). "The Determinants and Implications of Corporate Cash Holdings". Journal of Financial Economics, 52(1): 3-46. doi:https://doi.org/10.1016/S0304-405X(99)00003-3

Sargon, B., \& Katircioğlu, S. (2019). “The Role of Innovation in Venture Capital: Empirical Evidence from European Union and EFTA Countries”. Applied Economics Letters, 26(4): 335-340. doi:10.1080/13504851.2018.1470310 Retrieved from https://www.tandfonline.com/doi/pdf/10.1080/13504851.2018.1470310?needAccess=true

Shin, H.-H., \& Soenen, H. L. (1998). "Efficiency of Working Capital and Corporate Profitability". Financial Practice \& Education, 8(2): 37-45.

Stock, J. H., \& Yogo, M. (2002). Testing for weak instruments in linear IV regression 0898-2937).

Uyar, A. (2009). "The Relationship of Cash Conversion Cycle with Firm Size and Profitability: An Empirical Investigation in Turkey". International Research Journal of Finance and Economics, 24(2): 186-193.

Wang, B. (2019). “The Cash Conversion Cycle Spread”. Journal of Financial Economics, 133(2): 472-497.

Yazdanfar, D., \& Öhman, P. (2014). "The Impact of Cash Conversion Cycle on Firm Profitability: An Empirical Study Based on Swedish Data". International Journal of Managerial Finance, 10(4): 442-452. 